\title{
ESTABLISHING AN INTERNATIONAL COURT AGAINST TERRORISM
}

DOI: $10.47743 /$ rdc-2015-1-0003

\author{
Bogdan AURESCU, PhD \\ Professor, Faculty of Law, \\ University of Bucharest; \\ Minister of Foreign Affairs of Romania
}

Ion GÂLEA, PhD

University Lecturer, Faculty of Law, University of Bucharest;

Director-general for Legal Affairs in the Ministry

of Foreign Affairs of Romania

\section{Abstract}

The paper presents the initiative to create an International Court against Terrorism. The initiative was launched by Romania and Spain, in February 2015, against the background of tragic events in Europe. The paper exposes the grounding ideas beneath this initiative, mainly that terrorism is a global threat and that a response to it must be global and must be based on the rule of law and provides insight in the historical background on which it was launched. The efforts of the international community, dating back to the 1920's, towards regulating terrorism in a comprehensive manner and towards creating a permanent international jurisdiction to prosecute persons guilty of committing terrorist acts are exposed. The article also presents the current challenges linked to the definition of terrorism and exposes the proposal to overcome these difficulties by creating an international jurisdiction capable of prosecuting individuals who commit terrorist acts. The main features of the proposals are shown: an international Court, based on the principle of complementarity (in relation to national courts and the ICC), functioning in a flexible and efficient manner, created by the Security Council through a resolution under Chapter VII of the Charter and exercising its jurisdiction ratione materiae based on an international law definition, that would combine elements of customary law with an open list of acts described in the existing sectorial conventions against terrorism.

Keywords: International Court against Terrorism; terrorism; international jurisdiction; complementarity; Security Council

\footnotetext{
* The authors thank Alina Orosan and Matei Cristea for their valuable contribution to this paper. The opinions expressed in this paper belong solely to the authors and do not engage the institutions they belong to.
}

REVISTA DE DREPT CONSTITUŢIONAL 
Throughout the last decades, terrorism has been a growing concern and persistent topic on the international agenda, as one of the most serious threats to international peace and security. Recent events in Europe at the beginning of 2015 have proved not only the growth in frequency and atrocity of the terrorist acts, but have equally illustrated the need for increased involvement and action of the international community to this global threat. Each country has firm obligations to fight against terrorism, but there is equally the responsibility of the international community to use all tools of international law in order to combat the terrorist phenomenon.

Even if efforts towards creating international instruments for a global response to terrorism have been envisaged since the 1920's, progress remained low. International demarches remained fragmented and the international community still did not agree on important issues like a comprehensive definition of terrorism (even if it may be considered that the word "terrorism" itself does not embody legal significance ${ }^{1}$ ) or the creation of an international jurisdictional mechanism that would prosecute persons committing the gravest terrorist acts. However, during this entire period, international law and international criminal law progressed: the International Criminal Court is a functioning mechanism; several international ad-hoc criminal tribunals have been created. These developments might serve as examples towards advancing a proposal for the creation of an international court competent for prosecution of persons committing terrorist acts.

To this day, international fight against terrorism is conducted, on one hand, on the "security paradigm", which may comprise: national security measures, national and international sanctions (which are based on criteria, but in certain cases are not subject to judicial review), as well as measures involving use of force in the exercise of the inherent right to self-defense, and, on the other hand, on the "law enforcement paradigm", which relies essentially on the application of national criminal law and international cooperation in criminal matters between States ${ }^{2}$. This system lacks, indeed, a mechanism relying on international criminal law and an international body capable of exercising jurisdiction.

On 9 February 2015, the minister of foreign affairs of Romania launched within the framework of the EU Foreign Affairs Council the idea to create an International Court against Terrorism ${ }^{3}$. The initiative was joined by $\operatorname{Spain}^{4}$ and, today, both countries are

\footnotetext{
${ }^{1}$ R. Higgins, The general international law on terrorism, in Rosalyn Higgins, M. Flory (ed.), International Law and Terrorism, London, 1997, p. 28.

${ }^{2}$ See, for example, Bibi van Ginkel, The New Security Council Resolution 2178 on Foreign Terrorist Fighters: A Missed Opportunity for a Holistic Approach, International Center for Counter Terrorism Research Paper, 4 November 2014, available at http://icct.nl/publication/the-new-security-council-resolution-2178-on-foreign-terrorist-fighters-a-missedopportunity-for-a-holistic-approach (accessed 30 July 2015).

${ }_{3}^{3}$ Press release, Participarea ministrului afacerilor externe Bogdan Aurescu la reuniunea Consiliului Afaceri Externe, 9 February 2015, available at $h t t p: / / w w w . m a e . r o / n o d e / 30571$, accessed 30 July 2015.

${ }^{4}$ Press Statement, Margallo espera que prospere la Corte Penal Internacional sobre terrorismo al contar con "respaldo suficiente", Europa Press, 13 March 2015, available at http://www.europapress.es/nacional/noticia-margallo-esperaprospere-corte-penal-internacional-terrorismo-contar-respaldo-suficiente-20150513133119.html (accessed 30 July 2015).
} 


\section{Bogdan AURESCU • Ion GÂLEA}

working together for refining the legal elements of this initiative and for its promotion: at diplomatic level and in relation to the civil society and the academia. The legal research and drafting has also benefitted from the support of an expert from the Netherlands ${ }^{5}$. Still, a lot of work is still to be done, both at legal and diplomatic level.

This paper elaborates on the main features of the initiative to create an International Court against Terrorism. It envisages presenting the past efforts towards creating legal tools for fighting terrorism, shortly examining the difficult issue of the definition of terrorism. It also provides arguments for the establishment of an international jurisdiction against terrorism and exposes the main element of the legal architecture of the future Court.

On an overall basis, an important conceptual element should be outlined at the very beginning: the initiative would be based on the guiding idea that the rule of law is a value per se. Terrorism is a global threat; a response to it must be global and must be based on the rule of law. This is the reason why the best tool should be an institutional instrument based on international criminal law.

\section{The long way to find the perfect legal tool for fighting terrorism}

One of the earliest efforts to render terrorism universally punishable can be traced back to 1926, when Romania asked the League of Nations to "consider drafting a convention to render terrorism universally punishable". In 1934, after the assassination by terrorists, in Marseille, of the French Foreign Minister and of the King of Yugoslavia, the League of Nations created an expert committee for drawing an international convention "to assure the repression of conspiracies or crimes committed with a political or terrorist purpose $^{\prime \prime}$. The outcome of the work of the Committee was the adoption of the Convention on the Punishment and Prevention of Terrorism (which defined "acts of terrorism" Convention for the Creation of an International Criminal Court ${ }^{8}$ (which created the mechanism for the repression of acts of terrorism; it could be noted that in determining the substantial law applicable, the Court was to consider the law of the State on the territory of which the offence was committed and the law of the country that committed the accused to trial $^{9}$ ). The Romanian diplomat and jurist Vespasian Pella played a key role in the drafting of the abovementioned conventions. However, due to the international context of the World War II, these two instruments, signed by 24 States and ratified by one, never entered into force.

\footnotetext{
${ }^{5}$ Press release, MAE a iniţiat oficial consultări privind iniţiativa României de creare a unei Curţi Internaţionale pentru combaterea terorismului, 16 April 2015, available at http://www.mae.ro/node/31572 (accessed 30 July 2015).

${ }^{6}$ League of Nations, Official Journal, $15^{\text {th }}$ year, No. H (Part I), pp. 1839-1840.

7 League of Nations, Doc. C.546.M383.1937.V; Th. M. Franck. B.B. Lockwood, Preliminary Thoughts Towards and International Convention on Terrorism, AJIL, vol. 68 (1974), pp. 69-70.

${ }^{8}$ Historical Survey of the Question of International Criminal Jurisdiction, Memorandum Submitted by the Secretary General, Doc. A/CN.4/7/Rev.l, United Nations Publications, Sales No: 1949.V.8, p. 18, and Appendix 8.

${ }^{9}$ Ibidem, art. 21.
} 
Throughout the years, the danger raised by the terrorist phenomenon and its growing complexity have determined the international community to take into account different legal options and initiatives to fight against terrorism.

The International Law Commission considered terrorism within the 1954 Draft Code of Crimes against Peace and Security of Mankind ${ }^{10}$. Article 2 para. (6) of the Draft Code defined the crime of "undertaking or encouragement by the authorities of a State of terrorist activities in another State, or the toleration by the authorities of a State of organized activities calculated to carry out terrorist acts in another State". However, the Code was not considered by the UN General Assembly, due to the lack of agreement on the definition of terrorism.

Following the 1972 terrorist attacks against Israeli competitors within the Munich Olympic Games ${ }^{11}$, the United States presented a Draft Convention for the Prevention and Punishment of Certain Acts of International Terrorism. In the context of the debate of that time between developed and developing States, particularly over self-determination, the initiative was not pursued by the General Assembly.

Proposals related to the crime of terrorism were presented in the context of establishing the International Criminal Court. Article 5 of the 1998 Draft Rome Statute contained three terrorism-related offences ${ }^{12}$. Although a number of States supported the general approach, the Rome Statute did not include terrorism-related crimes, inter alia, due to the lack of a universally accepted definition and to certain disagreement about liberation movements. At the same time it was not agreed that universal jurisdiction exists with regard to this crime as opposed to the other crimes included in the Rome Statute.

\footnotetext{
${ }_{10}$ Adopted by the International Law Commission at its sixth session, in 1954, and submitted to the General Assembly as a part of the Commission's report covering the work of that session (para. 54); Yearbook of the International Law Commission, 1954, vol. II, p. 134.

${ }^{11}$ Eleven Israeli athletes were killed in the attack.

${ }^{12}$ Article 5 of the 1998 Draft Rome Statute, presented to the 1998 Rome Diplomatic Conference, included 'crimes of terrorism' comprising three distinct offences: "For the purposes of the present Statute, crimes of terrorism means: (1) Undertaking, organizing, sponsoring, ordering, facilitating, financing, encouraging or tolerating acts of violence against another State directed at persons or property and of such a nature as to create terror, fear or insecurity in the minds of public figures, groups of persons, the general public or populations, for whatever considerations and purposes of a political, philosophical, ideological, racial, ethnic, religious or such other nature that may be invoked to justify them; (2) An offence under the following Conventions: (a) Convention for the Suppression of Unlawful Acts against the Safety of Civil Aviation; (b) Convention for the Suppression of Unlawful Seizure of Aircraft; (c) Convention on the Prevention and Punishment of Crimes against Internationally Protected Persons, including Diplomatic Agents; (d) International Convention against the Taking of Hostages; (e) Convention for the Suppression of Unlawful Acts against the Safety of Maritime Navigation; (f) Protocol for the Suppression of Unlawful Acts against the Safety of Fixed Platforms located on the Continental Shelf; (3) An offence involving use of firearms, weapons, explosives and dangerous substances when used as a means to perpetrate indiscriminate violence involving death or serious bodily injury to persons or groups of persons or populations or serious damage to property" (A/CONF.183/2/Add.1).
} 


\section{Bogdan AURESCU • Ion GÂLEA}

The proposal was put again forward by the Netherlands in 2009, while preparing for the Kampala Conference for the Revision of the ICC Statute. The proposal ${ }^{13}$ envisaged a similar mechanism to the one initially envisaged by the Statute for the crime of aggression: the inclusion of the crime of terrorism within the jurisdiction of the Court, while postponing the exercise of jurisdiction until the crime is defined. Although the proposal was not rejected, the discussions have been postponed for a later moment.

Developments regarding combating terrorism can also be traced in the establishment by an Agreement between the UN and Lebanon ${ }^{14}$ of the Special Tribunal for Lebanon, a "hybrid" international court, applying the Lebanese criminal law relating to the prosecution and punishment of, inter alia, acts of terrorism.

\section{The cornerstone: a definition of terrorism}

The term 'terrorism' first appeared at the Third Conference in Brussels in $1930^{15}$, being defined as "The intentional use of means capable of producing a common danger that represents an act of terrorism on the part of anyone making use of crimes against life, liberty or physical integrity of persons or directed against private or state property with the purpose of expressing or executing political or social ideas will be punished".

In 2000, the United Nations General Assembly instructed the Ad Hoc Committee for drafting a Comprehensive Convention on International Terrorism ${ }^{16}$ to begin 'consideration with a view to the elaboration of a comprehensive convention on international terrorism within a comprehensive legal framework of conventions dealing with international terrorism ${ }^{17}$. To date this aim has not been met. One of the major obstacles in the attempt to reach a consensus on the definition of terrorism is the disagreement on issues related to acts of armed forces and liberation movements.

Despite these difficulties, the legal action of the international community in fighting terrorism took concrete forms in the adoption of a significant number of specific sectorial counter-terrorism conventions and of several Security Council resolutions ${ }^{18}$.

\footnotetext{
${ }_{13}$ Assembly of State Parties, Report of the Bureau on the Review Conference, Eighth session, The Hague, 18-26 November 2009, ICC-ASP/8/43, p. 6, para. 20-22.

14 The Agreement was brought in force by Resolution 1757 (2007) of the UN Security Council.

${ }^{15}$ As shown in Ben Saul, Attempts to Define 'Terrorism' in International Law, The University of Sydney, Sydney Law School, Legal Studies Research Paper, No.8/115, October 2008, p. 2.

16 The Ad-hoc Committee was created by UNSC Resolution A/Res/51/210 (17 December 1996), Measures to eliminate international terrorism (operational para. 9).

17 UNSC Resolution A/Res/54/110 (2 February 2000) Measures to eliminate international terrorism (operational para. 12).

18 UNSC Resolutions 2161 (2014), 217 (2014), 2178 (2014), 2199 (2015); see also Ben Saul, Defining Terrorism in International Law, Oxford University Press, 2006, p. 48.
}

REVISTA DE DREPT CONSTITUŢIONAL 
Within the United Nations, the terrorism-related activity proved to be fragmented. The failure to achieve agreement on a comprehensive convention has led to the existence of sector-specific international legislation. Nineteen universal legal instruments regulating specific aspects of terrorism have been adopted so far in areas as varied as: air security, maritime security, the financing of terrorism, the use of certain types of weapons, or the protection of certain types of persons. This international legislation is fragmented and clearly insufficient for effectively addressing the challenges that terrorism currently presents to the international community.

Indeed, regional organisations proved to be willing to act with legal tools to counter terrorism. A number of international treaties and rules on terrorism also exist at a regional scale. In the framework of the League of Arab States, the 1998 Arab Convention on the Suppression of Terrorism contains detailed provisions concerning the definition of terrorism and terrorist offences ${ }^{19}$. The 2002 Inter-American Convention against Terrorism, adopted in the framework of the Organization of American States, provides for trans-border cooperation in combating the offences defined in a number of sectoral international conventions ${ }^{20}$.

\footnotetext{
${ }^{19}$ Art. 1 para. 2. Terrorism: Any act or threat of violence, whatever its motives or purposes, that occurs for the advancement of an individual or collective criminal agenda, causing terror among people, causing fear by harming them, or placing their lives, liberty or security in danger, or aiming to cause damage to the environment or to public or private installations or property or to occupy or to seize them, or aiming to jeopardize a national resource.

Art. 1 para. 3. Terrorist offence: Any offence or attempted offence committed in furtherance of a terrorist objective in any of the Contracting States, or against their nationals, property or interests, that is punishable by their domestic law. The offences stipulated in the following conventions, except where conventions have not been ratified by Contracting States or where offences have been excluded by their legislation, shall also be regarded as terrorist offences: a. The Tokyo Convention on offences and Certain Other Acts Committed on Board Aircraft, of 14 September 1963; b. The Hague Convention for the Suppression of Unlawful Seizure of Aircraft, of 16 December 1970; c. The Montreal Convention for the Suppression of Unlawful Acts against the Safety of Civil Aviation, of 23 September 1971, and the Protocol thereto of 10 May 1984; d. The Convention on the Prevention and Punishment of Crimes against Internationally Protected Persons, including Diplomatic Agents, of 14 December 1973; e. The International Convention against the Taking of Hostages, of 17 December 1979; f. The provisions of the United Nations Convention on the Law of the Sea, of 1982, relating to piracy on the high seas.

${ }^{20}$ Article 1 (Object and purpose): The purposes of this Convention are to prevent, punish and eliminate terrorism. To that end, the states parties agree to adopt the necessary measures and to strengthen cooperation among them, in accordance with the terms of this Convention.

Article 2 (Applicable international instruments): 1. For the purposes of this Convention, "offenses" means the offenses established in the international instruments listed below: a) Convention for the Suppression of Unlawful Seizure of Aircraft, signed at The Hague on December 16, 1970; b) Convention for the Suppression of Unlawful Acts against the Safety of Civil Aviation, signed at Montreal on September 23, 1971; c) Convention on the Prevention and Punishment of Crimes against Internationally Protected Persons, including Diplomatic Agents, adopted by the General Assembly of the United Nations on December 14, 1973; d) International Convention against the Taking of Hostages, adopted by the General Assembly of the United Nations on December 17, 1979; e) Convention on the Physical Protection of Nuclear Material, signed at Vienna on March 3, 1980; f)Protocol on the Suppression of Unlawful Acts of Violence at Airports Serving International Civil Aviation, supplementary to the Convention for the Suppression of Unlawful Acts against the Safety of Civil Aviation, signed at Montreal on February 24, 1988; g) Convention for the Suppression of Unlawful Acts against the Safety of Maritime Navigation, done at Rome on March 10, 1988; h) Protocol for the Suppression of Unlawful Acts against the Safety of Fixed Platforms Located on the Continental Shelf, done at Rome on March 10, 1988; i) International Convention for the Suppression of Terrorist Bombings, adopted by the General Assembly of the United Nations on December 15, 1997; j) International Convention for the Suppression of the Financing of Terrorism, adopted by the General Assembly of the United Nations on December 9, 1999.
} 


\title{
Bogdan AURESCU • Ion GÂLEA
}

At European level, both the Council of Europe and European Union have produced work in this direction. Notable with regard to the former is Convention 196 on the Prevention of Terrorism ${ }^{21}$ (Warsaw, 2005). As for the European Union, it has, since the adoption of the Treaty of Lisbon, been authorized to establish minimum rules concerning the definition of criminal offences and sanctions in the areas of particularly serious crime with a cross-border dimension, including terrorism ${ }^{22}$ (Art. 83 para. 1 TFEU).

Various definitions of terrorism are to be found as well in the national legislations of States ${ }^{23}$ and in the jurisprudence of the national jurisdictions.

\begin{abstract}
${ }^{21}$ Art. 1. Terminology: For the purposes of this Convention, "terrorist offence" means any of the offences within the scope of and as defined in one of the treaties listed in the Appendix.

${ }_{22}$ According to art. 1 of the Framework Decision no. 2002/475/JHA on Combating Terrorism (OJ L 164 of 22 June 2002, pp. 3-7), terrorism are certain criminal offences set out in a list consisting largely of serious offences against persons and property that, given their nature or context, may seriously damage a country or an international organisation where committed with the aim of: seriously intimidating a population; or unduly compelling a Government or international organisation to perform or abstain from performing any act; or seriously destabilising or destroying the fundamental political, constitutional, economic or social structures of a country or an international organization.
\end{abstract}

${ }^{23}$ Some examples of such definitions: According to the Indian Terrorist and Disruptive Activities (Prevention) Act, whoever with intent to overawe the Government as by law established or to strike terror in the people or any section of the people or to alienate any section of the people or to adversely affect the harmony amongst different sections of the people does any act or thing by using bombs, dynamite or other explosive substances or inflammable substances or lethal weapons or poisons or noxious gases or other chemicals or by any other substances (whether biological or otherwise) of a hazardous nature in such a manner as to cause, or as is likely to cause, death of, or injuries to, any person or persons or loss of, or damage to, or destruction of, property or disruption of any supplies or services essential to the life of the community, or detains any person and threatens to kill or injure such person in order to compel the Government or any other person to do or abstain from doing any act, commits a terrorist act. In the UK Terrorism Act of 2000, "terrorism" means the use or threat of action where: (a) the action falls within subsection (2), (b) the use or threat is designed to influence the government or to intimidate the public or a section of the public and (c) the use or threat is made for the purpose of advancing a political, religious or ideological cause. (2) Action falls within this subsection if it: (a) involves serious violence against a person; (b) involves serious damage to property; (c) endangers a person's life, other than that of the person committing the action; (d) creates a serious risk to the health or safety of the public or a section of the public or (e) is designed seriously to interfere with or seriously to disrupt an electronic system. According to the same document, terrorism include not only violent offences against persons and physical damage to property, but also acts "designed seriously to interfere with or to seriously disrupt an electronic system" if those acts are (a) designed to influence the government or to intimidate the public or a section of the public, and (b) be done for the purpose of advancing a political, religious or ideological cause.

Title 18 of the United States Code (regarding criminal acts and criminal procedure) defines international terrorism as "involving activities activities that (A) involve violent acts or acts dangerous to human life that are a violation of the criminal laws of the United States or of any State, or that would be a criminal violation if committed within the jurisdiction of the United States or of any State; (B) appear to be intended: (i) to intimidate or coerce a civilian population; (ii) to influence the policy of a government by intimidation or coercion; or (iii) to affect the conduct of a government by mass destruction, assassination, or kidnapping; and (C) occur primarily outside the territorial jurisdiction of the United States, or transcend national boundaries in terms of the means by which they are accomplished, the persons they appear intended to intimidate or coerce, or the locale in which their perpetrators operate or seek asylum". The U.S. Code of Federal Regulations (28 C.F.R. Section 0.85) defines terrorism as "the unlawful use of force and violence against persons or property to intimidate or coerce a government, the civilian population, or any segment thereof, in furtherance of political or social objectives", whereas The U.S. National Counterterrorism Center (NCTC) considers that terrorism is "premeditated; perpetrated by a sub-national or clandestine agent; politically motivated, potentially including religious, philosophical, or culturally symbolic motivations; violent; and perpetrated against a non-combatant target".

REVISTA DE DREPT CONSTITUTTIONAL 
The jurisprudence of the Special Tribunal for Lebanon is also of relevance in identifying the elements of the crime of terrorism. In the interlocutory decision of 16 February 2011, the Appeals Chamber of the Special Tribunal acknowledged the existence of a rule of customary international law according to which the crime of terrorism would include the intention to commit an act (dolus), the special intention to spread fear and constrain the authorities (dolus specialis), as well as the concrete performance of the act and its transnational character ${ }^{24}$. The Special Tribunal held:

"As we shall see, a number of treaties, UN resolutions, and the legislative and judicial practice of States evince the formation of a general opinio juris in the international community, accompanied by a practice consistent with such opinio, to the effect that a customary rule of international law regarding the international crime of terrorism, at least in lime of peace, has indeed emerged. This customary rule requires the following three key elements: (i) the perpetration of a criminal act (such as murder, kidnapping, hostage-taking, arson, and so on), or threatening such an act; (ii) the intent to spread fear among the population (which would generally entail the creation of public danger) or directly or indirectly coerce a national or international authority to take some action, or to refrain from taking it; (iii) when the act involves a transnational element" ${ }^{25}$.

The lack of a general accepted definition of terrorism has been analyzed broadly in the legal doctrine. On the basis of the sectorial conventions and relevant resolutions, there has been identified in the doctrine a core meaning of terrorism that arguably could be considered as the minimal definition of international terrorism on which consensus might be considered to have been reached: "[T]he majority of the definitions have a common basis - terrorism is the use of violence and the imposition of fear to achieve a particular purpose" $^{26}$.

\section{Beyond the definition - an international jurisdictional reply}

\section{to terrorism}

An option that could be revisited in the context of the resurrection of terrorism and its tendency to widespread would be the establishment of an international court for sanctioning terrorism, taking up the old Pella's idea.

\footnotetext{
${ }^{24}$ Interocultory decision on the applicable law: terrorism, conspiracy, homicide, perpetration, cumulative charging of 16 February 2011 (Case STL-11/01/I).

25 Ibidem, pp. 49-50, para. 85.

${ }^{26}$ R. Young, Defining Terrorism: The Evolution of Terrorism as a Legal Concept in International Law and Its Influence on Definitions in Domestic Legislation, 29 B.C. Int'l \& Comp. L. Rev. 23 (2006), available at http://lawdigitalcommons. bc.edu/iclr/vol29/iss1/3, p. 33.
} 


\section{Bogdan AURESCU • Ion GÂLEA}

Such an initiative would certainly acknowledge the transnational nature of terrorism and the grave effects on the international community as a whole, the fact that some States are unable or unwilling to bring to justice the persons within their jurisdiction that commit terrorist acts and the need to approach it at an international level. It would strengthen the efforts of the international community in the fight against terrorism and would add credibility and legitimacy to this demarche due to the neutrality and independence of such an international tribunal.

As terrorism is a global phenomenon, which poses increasingly complex challenges, there is a need to tackle this issue globally, taking into account all possibilities and all tools of international law, including the adoption of instruments of universal applicability and the creation of an international court dealing with acts of terrorism, which would complement the activity of national authorities ${ }^{27}$. Applying the principle of complementarity would reinforce the domestic capacity of States to address criminal law action against terrorism.

\section{The basis, the principles and the framework of the new court}

\subsection{Legal foundation}

Ideally, as all major international projects, such a court should be created through an international treaty. It would certainly confer the new court a strong and coherent legal basis, world-wide international support and commitment. However, the experience of the other international major criminal tribunal shows that a lot of time must be invested in getting such a court to universal participation and, hence, to universal jurisdiction. Terrorism has grown so much more significantly and developed so much more rapidly that a quick reaction on the part of the whole international community is needed in order to prevent its spreading and protect the life and physical integrity of the individual human being and give meaning to the human right from fear.

The quicker option for setting up the court would be the action of the Security Council on the basis of Chapter VII of the UN Charter (similarly to the ad-hoc tribunals established for ex-Yugoslavia and for Rwanda). Such an action would require, as a prerequisite, the establishment that terrorism is a threat to international peace and security ${ }^{28}$, otherwise the

\footnotetext{
${ }^{27}$ Concerning a proposal for a international court to suppress terrorism, see: Bibi van Ginkel, How to Repair the Legitimacy Deficit in the War on Terror: A Special Court for Dealing with International Terrorism?, in J. de Swaan, E. Bakker and S. van der Meer (eds.), Challenges in a Changing World; Clingendael Views on Global and Regional Issues, TMC Asser Press, 2009, pp. 145-162; Bibi van Ginkel, Combating Terrorism: Proposals for Improving the International Legal Framework, in A. Cassese (ed.), Realizing Utopia: The Future of International Law, Oxford University Press, 2012, p. 479.

28 In 2001, following the September 11 attacks, the United Nations Security Council declared that "acts of international terrorism constitute one of the most serious threats to international peace and security in the twentyfirst century" [S.C. Res. 1377, Annex, U.N. Doc. S/RES/1377 (Nov. 12, 2001)].
}

REVISTA DE DREPT CONSTITUŢIONAL 
Security Council not being in a position to act. On the other side, departing from the examples of the ad-hoc tribunals, such a court would not respond to a specific well identified situation in time and space, but to the general threat that terrorism would raise worldwide, after its creation. Such an action on the part of the Security Council would certainly be rather unprecedented ${ }^{29}$.

\subsection{The applicable principles}

In order to be efficient and effective in fighting terrorism and avoid creating "safe havens" for terrorist related activities, the court should enjoy universal jurisdiction. Such an aim would definitely be attained in the shortest possible delay through a Security Council resolution establishing the Court. Otherwise the participation of states in an international convention would require time at least in fulfilling the national legal procedures for expressing consent to become a party to such a treaty.

The court should work on the basis of a dual complementarity:

a) First, it should be complementary to the national courts and should act only in those cases in which the competent state/ states is/are unwilling or unable to act in view of sanctioning the perpetrated act of terrorism. In such a manner the court would best act in view of strengthening the national capacity to fight terrorism ${ }^{30}$;

b) Second, it should be complementary to the jurisdiction of the International Criminal Court in those cases of acts of terrorism which amount to crimes within the established jurisdiction of the ICC.

The efficiency of the court in discharging its mandate would greatly depend on the cooperation of States in gathering evidence, executing arrest warrants etc., since international courts in general do not benefit of specific police organs for themselves. Theoretically, there could be a decision on the part of the Security Council, for instance, for the creation of such multinational police force to support the activity of the Court in those cases in which the Security Council has determined that the required State/s is/are unable or unwilling to cooperate in a certain case. Therefore, rather than being a permanent organ of the court, such a "police force" could have an ad-hoc mandate and be activated as the situation requires. Such a decision, however, would certainly require an impressive political determination on the part of the international community, given the sensitivities (especially from the point of view of national sovereignty and national security) it involves.

\footnotetext{
${ }^{29}$ However, with respect to the powers of the Council, the decision of the ICTY in Tadic (Appeal on Motion on Jurisdiction, 2 October 1995) could be recalled: "Article 39 leaves the choice of means and their evaluation to the Security Council, which enjoys wide discretionary powers in this regard; and it could not have been otherwise, as such a choice involves political evaluation of highly complex and dynamic situations" (para. 39).

${ }^{30}$ Complementarity in this case would be similar to the one enshrined in article 17 of the Statute of the International Criminal Court: see, in this sense, The Prosecutor v Francis Kirimi Muthaura, Uhuru Muigai Kenyatta and Mohammed Hussein Ali (ICC-01/09-02/11 OA), Decision of the Appeals Chamber, 6 June 2011.
} 


\section{Bogdan AURESCU • Ion GÂLEA}

\subsection{Jurisdiction}

On substance, defining the ratione materiae jurisdiction of the new court is essential for clearly setting up its mandate and role in the international legal arena. Despite known difficulties in achieving a generally-accepted legal definition of terrorism, as revealed by the Special Tribunal for Lebanon in its interlocutory judgment, sufficient elements of this concept have gradually materialized in customary international law to allow for the determination of the crime of terrorism as a subject-matter jurisdiction for the future international court. A definition based on two segments can thus be imagined: (i) the acts listed in the UN sectorial counter-terrorist conventions and (ii) an "open" general definition, founded on elements recognized in customary international law and jurisprudence (especially the case law of the Special Tribunal for Lebanon): the existence of criminal intent in the perpetration of the acts (dolus), the specific intent of causing terror or coercing authority (dolus specialis), the perpetration of a criminal act, and, where applicable, the gravity of the acts, that may constitute a threat to international peace and security.

As far as ratione personae jurisdiction is concerned, similarly to other international jurisdiction, the criminal responsibility would be individual in nature and would concern perpetrators having reached the age of 18 , regardless of political, military, or any other position held.

The ratione temporis jurisdiction bears a distinction in between the duration of the mandate of such an international tribunal (temporary vs. permanent) - a matter to be clarified in the instrument creating the court - and the competence of the court to deal only with criminal acts perpetrated after its creation ("pro futuro" competence).

Lastly, with regard to ratione loci jurisdiction, since terrorism is not confined to any specific location, and given the ever-changing nature of the locations targeted by such acts, it would appear more appropriate to establish a court with aspirations of worldwide jurisdiction.

On procedure, the court would exercise its jurisdiction following a State referral (based on a territoriality principle, as well as active and passive personality principle), proprio motu or following a UN Security Council finding. However, the triggering mechanism of the jurisdiction of the Court would depend much on the legal instrument that creates the Court, the options, as detailed above, being an international treaty or a Security Council action on the basis of Chapter VII of the UN Charter.

\subsection{The institutional design}

The structure and functioning of the future Court should ensure jurisdictional guarantees under the rule of law. This requires that a minimum number of judges be provided so as to represent the different legal cultures from around the world, chambers before which decisions can be duly reviewed, and a Prosecutor's Office. General principles of criminal law derived from national laws of legal systems of the world will be also taken into account in defining the procedural mechanism of the international court. 
The design of the court would certainly depend much on cost efficiency calculations. Following the principles governing the functioning of other tribunal with international character, the Court could have 11-15 judges, chosen from among persons of high moral character, impartiality and integrity, with established high competence in the field of international law/criminal law, taking into account the principles of equitable geographical distribution, the representation of the principal legal systems of the world and a fair representation of female and male judges.

\section{Conclusion}

International terrorism is a plague that requires global action, but this global action should be conducted also "with the weapons of law". The initiative presented above relies on the guiding idea that the Rule of Law and international justice are values per se. Respect for international law is one of the cornerstones of Romania's foreign policy. However, these values must be supplemented by concrete tools, needed to make international law and justice efficient. International Courts and Tribunals are such tools.

It is absolutely true that the initiative contains very ambitious elements and issues comprising legal difficulties. The definition of terrorism, the relation with the ICC and the powers of the Security Council to create a new court are maybe the most important of these challenges.

However, the process of promoting this initiative may prove highly valuable. Discussions could generate a "brainstorming" that would help overcome, through innovative legal solutions, existing divergence between States. Maybe the result of such an initiative would have impact in some other place: like concluding the negotiations on the Comprehensive Convention against Terrorism.

Moreover, what is important to state is that the success of the initiative depends on the genuine will of the international community of States to approach international terrorism in a holistic manner, in line with the principles of the rule of law. The support of the civil society and academia are crucial towards this purpose. A lot of work still needs to be done, but the most important point of departure for all demarches should be reliance on values: justice, rule of law, and multilateralism. 